Rev. Pawet Mąkosa

Catholic University of Lublin

DOI: $10.15290 /$ rtk.2019.18.10

iD 0000-0002-4664-7024

\title{
The Roman Catholic Church's Late Medieval Teaching on Eschatology as the Basis for Visual Catechesis"
}

This article reflects on the Catholic Church's teaching on eschatology at the end of the Middle Ages. These teachings serve as the preliminary basis of an analysis of the visual catechesis depicted in medieval frescoes and paintings of the Last Judgment. The article will examine the Second Council of Lyons (1274), apostolic constitution Benedictus Deus (1336), and the Council of Florence's (1439) teaching on eschatology. The specific teachings that this article will address are: particular judgment and the Last Judgment, the essence of the beatitude experienced by those who are saved (visio beaticifa), and the existence of purgatory and what, precisely, it is.

Key words: eschatology, catechesis, iconography, Last Judgment.

For centuries, visual depictions formed an important (and sometimes even the most basic) tool for Christian catechesis. Frescos and paintings illustrated and explained the truths of faith especially to the illiterate and those who did not have access to the Holy Bible and literature. Although they reflected the artistic vision of their creators, these depictions were based primarily on the official teachings of the Roman Catholic Church, which was conveyed either through preaching or theological reflection. Among the different religious works of art, eschatological depictions were the most common. Indeed, paintings of the Last Judgment were often painted on the back walls of churches in

* The project is funded by the Minister of Science and Higher Education within the program under the name "Regional Initiative of Excellence" in 2019-2022, project number: 028/RID/2018/19, the amount of funding: 11742500 PLN. 
order to remind the faithful about their final destiny as they departed after the celebration of the Holy Mass or devotions.

The present article analyzes the Magisterium of the Church's teaching on eschatology in the late Middle Ages, which then served as the substantive basis of the visual depictions of the Last Judgment created during this period. In particular, this article will first examine the official statements formulated by the Magisterium in the fourteenth and fifteenth centuries (i.e., at the end of the Middle Ages). The study will present different ecumenical councils' dogmatic proclamations and official documents as well as the most important statements on eschatology promulgated by the popes of that time. The Second Council of Lyons, which was convened in 1274 in order to bring about reconciliation between the Latin and Greek Churches, ${ }^{1}$ played a particularly important role in the formulation of doctrines on eschatology during this period. In addition, this article will analyze Pope Benedict XII's apostolic constitution Benedictus Deus, which was issued on January 29,1336 . The creation of this document has a rather turbulent history and is connected to Pope John XXII's controversial teaching that the

Catechetics beatitude that the saved experience after their particular judgment is fundamentally different than the happiness that they experience after the Last Judgment. The Council of Florence, which convened in 1439 as the Roman Catholic Church continued to attempt to unite with the Eastern Orthodox Church ${ }^{2}$ subsequently played a valuable role in shaping doctrines on eschatology. One of the contentious issues that stood in the way of uniting the Latin and Eastern Churches was the Roman Catholic Church's teaching on purgatory. This article will systematically discuss the most important topics presented in the magisterial statements mentioned above-namely, particular and Last Judgment, the beatific vision, and purgatory.

\section{The Particular and Last Judgments}

The constitutions of the Second Council of Lyons make a distinction between the particular and the Last Judgment. One document, in particular, contains an important averment about the judgment of the entire world in which all people must stand "in their own bodies" before Christ's tribunal and account for the things that they have done

1 J. F. Kelly, The Ecumenical Councils of the Catholic Church: A History, Collegeville 2009, pgs. 216-219. 
throughout their entire lives before being rewarded or punished. ${ }^{3}$ When referring to the eternal reward or punishment, the Council of Lyons used the word "immediately" (mox), which indirectly confirms that there is an individual particular judgment that takes place right after death. This particular judgment determines the soul's fate. According to the Conciliar Fathers, both those who are saved and the damned receive their reward or punishment, respectively, immediately after the soul is separated from the body. ${ }^{4}$ At the same time, the Council adds that everyone will stand before Christ again at the Judge at the Last Judgment at the end of the world. In this case, however, each person will be in his own body, which will also receive its reward or punishment. ${ }^{5}$ When referring to the Last Judgment, the Council confirms the existence of hell, declaring that those who die in mortal sin or in the state of original sin will immediately go to hell where various punishments await them. ${ }^{6}$ The document, therefore, defines the different types of sin (mortal and original) that merit eternal damnation and speaks of the diversity of punishments. The Council documents also mention that the Parousia, or the second coming of Christ, will crown the history of mankind. In this way, it serves as the Church's confession of faith that Christ will return at the end of time and judge the living and the dead.

Benedict XII also took up the issue of the two types of judgment (i.e., particular and Last judgment) in his apostolic constitution Benedictus Deus. In this document, he does not explicitly formulate the concept of particular judgment (iudicium particulare), but this idea follows logically from the dogmatic ruling that each person will give a full account of his life and be judged immediately after his death. ${ }^{7}$ If each person is either rewarded or punished for what he has done during his life, then God must make an act of judgment prior to the individual's death. In principle, the document confirms the teaching of the Second Council of Lyons that stresses that immediate eternal retribution does not diminish the significance of the Last Judgment.

3 H. Denzinger, A. Schönmetzer, Enchiridion Symbolorum Definitionum et Declarationum de Rebus Fidei et Morum, Freiburg 1965, no. 859. Ibid, nos. 857-858.

See: T. Horváth, Eternity and Eternal Life: Speculative Theology and Science in Discourse, Waterloo 1993, p. 19.

H. Denzinger, A. Schönmetzer, Enchiridion Symbolorum, nos. 858-859; J. Finkenzeller, Eschatologia, Cracow 2000, pg. 213.

Por. T. D. Łukaszuk, Ostateczny los człowieka iświatawświetle wiarykatolickiej, Cracow 2006, pg. 105. 
The necessity of a general judgment at the end of time was justified by the bodily and spiritual nature of man, who must stand in body and soul before God's judgment. ${ }^{8}$ Benedictus Deus maintains a clear distinction between individual eschatology related to particular judgment and general eschatology related to the Last Judgment and Parousia. In the document, the truth concerning the general resurrection of body is also found in the context of the Last Judgment. The document emphasizes the mutual bond and very close relationship between the body and the soul. The body is not only something external to the soul, but also that which expresses it. ${ }^{9}$ The soul is the essence and the form of the body, and that is why the soul remains corporal in a sense even after being separated from the body. ${ }^{10}$ Benedict XII, therefore, rejects purely spiritual interpretations by asserting that the resurrection of the body is an important aspect of the fulfillment of the salvific event. It should be noted, however, that issues concerning the eternal fate of the individual are the primary focus of Benedict XII's work, which marks a shift away from the general eschatology that was emphasized during the Patristic era to particular eschatology. ${ }^{11}$

\section{The Essence of the Beatitude of the Saved}

The beatitude of those who are saved is an important issue that is taken up in the Church's teaching at the end of the Middle Ages. Pope John XXII began a heated discussion on this subject when preaching to the bishops of Avignon, theologians, and members of the Roman Curia on the Solemnity of All Saints in $1331 .{ }^{12}$ Although the pope was only expressing his own theological views (and not speaking ex cathedra), because of the context of his preaching, his audience,

8 Por. F. J. Nocke, Eschatologie, Düsseldorf 1982, pgs. 74-78; por. T. D. Łukaszuk, Ostateczny los człowieka, pg. 111.

$9 \quad$ For theological discussions about the resurrection of the body in antiquity see: H. Pietras, Eschatologia Kościoła pierwszych czterech wieków, Cracow 2007; M. Wysocki, "Zmartwychwstanie ciała według Tertuliana," Verbum Vitae, 15 (2009), pgs. 295-324.

10 Por. C. W. Bynum, The Resurrection of the Body in Western Christianity 2001336, New York 1995, p. 278.

11 The eschatology of the Church Fathers and the ancient confessions of the faith primarily emphasized Parousia, the Last Judgment, and the resurrection of the body. See: L.F. Ladaria, "Kres człowieka i kres czasów," in: Człowiek i jego zbawienie. Historia dogmatów, ed. B. Susboüé, Cracow 2001, pgs. 384; 400.

12 C. Naumowicz, "Konstytucja Benedykta XII Benedictus Deus. Próba nowego spojrzenia na kontrowersję," Teologia w Polsce, 4 (2010), no. 1, p. 111. 
and the ceremonial character and location of his address, his words took on a particular significance and were understood as an official proclamation.

In his sermon, John XXII addressed the issue of the fate of those who are saved after death and the eternal reward of the righteous known as the beatific vision (visio beatifica), or the contemplation of God. John XXII pointed out the different manner in which the saved experience beatitude both before and after the Last Judgment. Before the Last Judgment, souls are separated from their bodies (anima separata). As a result, those who are saved cannot see God directly, meaning face to face (visio beatifica), because they are incomplete without their bodies and are not yet able to do so. Man is, therefore, a unity of body and soul. The pope claimed that it would be strange for the soul to enjoy the beatific vision before the general resurrection. ${ }^{13}$ Therefore, in his opinion, righteous souls experience only partial joy and await the complete beatitude in heaven that they will attain only after the resurrection [of the body]. Pope John XXII applied the traditional understanding of intermediate state (intermedius status), which is the period between man's death and the resurrection of his body. ${ }^{14}$ During this time, the human soul, which is no longer united with the body, undergoes its particular judgment and waits in anticipation of the Last Judgment, when it will be reunited with the body and judged again. ${ }^{15}$ In this regard, the pope referred to the principle of postponement, which was passed from antiquity and upholds that complete beatitude is certain but postponed until the Last Judgment. The logical consequence of these concepts was a belief in the existence of two separate places for the saved: a kind of "waiting area" where souls separated from the body end up immediately after their death and particular judgment and the place of fulfillment (i.e., proper heaven) where souls can fully enjoy eternal happiness after being reunited with their bodies on the last day. Pope John XXII further developed eschatology based on the principle of postponement ${ }^{16}$ in 1332 in his sermon for the Epiphany. In this homily, he spoke about postponement along with the fate of the damned. He stated that, like the complete beatitude of those who are

13 Por. M. Dykmans, Les sermons de Jean XXII sur la vision béatifique, Rome 1973, pgs. 114-116; C. W. Bynum, The Resurrection of the Body in Western Christianity 200-1336, pgs. 286-287.

J. Finkenzeller, Eschatologia, pgs. 102-106. 
saved (beholding God face-to-face), the final condemnation of sinners is also postponed until the Last Judgment. ${ }^{17}$

John XXII's statements were met with great criticism. His adversaries were mainly those who ran in the theological circles associated with the universities of Paris and Oxford and the Dominicans,${ }^{18}$ who acknowledged that the papal teaching was incompatible with the Church's already existing teaching based on St. Thomas Aquinas' theology. ${ }^{19}$ In 1334, Pope John XXII prepared the bull Ne Super His in which he retracted part of his previous views without making an official announcement. Instead, he only read a passage of the document on his deathbed. The papal bull contained the statement that the souls of the righteous are in heaven, even before the Last Judgment, and that they see God face to face to the degree to which a soul separated from its body permits (in quantum status et condicio compatitur animae separatae $\left.^{20}\right)$. This statement served as a kind of compromise, since it indicated that there is a qualitative difference between the experience of the visio beatifica before and after the Last Judgment and that the source of this difference is the role that the resurrected body of those Catechetics who are saved plays in the soul's experience of the complete eternal reward. ${ }^{21}$

In the papal bull Benedictus Deus, Pope Benedict XII proclaimed the Roman Catholic Church's official teaching on the essence of heaven and the beatific vision on January 29, 1336. The controversy surrounding John XXII's teaching, the theological deliberations taking place in Avignon in 1335, and Benedict XII's treatise De Statu Animarum Sanctorum Ante General Iudicium all served as the context from which Benedictus Deus arose. ${ }^{22}$

17 See: D. Douie, "John XXII and Beatific Vision," Dominican Studies 3 (1950) no. 2, pgs. 154-174; J. E. Weakland, "Pope John XXII and the Beatific Vision Controversy," Annuale Mediaevale 9 (1968), pgs. 76-84.

18 See: C. W. Bynum, The Resurrection of the Body in Western Christianity 2001336, p. 284; J. Finkenzeller, Eschatologia, p. 107; G. D’Onofrio, Historia teologii. Epoka średniowieczna, Cracow 2005, p. 497.

19 Thomas Aquinas stated that the beatific vision is the same before and after the Last Judgment. After the Parousia, however, the intensity with which the person experiences the beatific vision will increase, see: M. Dykmans, Pour et contre Jean XXII en 1333. Deux traites avignonnais sur la vision beatiflque, p. 50 .

H. Denzinger, Enchiridion symbolorum definitionum et declarationum de rebus fidei et morum, Bologna 2004, pgs. 520-521.

D. Douie, John XXII and Beatific Vision, p. 157.

T. D. Łukaszuk, Ostateczny los człowieka, p. 103; C. Naumowicz, "Konstytucja Benedykta XII Benedictus Deus,” p. 113. 
The consitution Benedictus Deus defines visio beatifica as an intuitive, face-to-face vision of God without another creature's mediation. This vision is possible due to the divine essence's clear and full revelation of Itself. Benedictus Deus addresses and clarifies three of the four issues that were at the heart of previous disputes. First, the document states that the soul separated from the body (anima separate) will enjoy the beatific vision immediately after death. Secondly, the vision will be manifested "plainly, clearly and openly" so that it becomes a source of true happiness and rest (requiem). Thirdly, with this vision, all acts of faith and hope will be done away with..$^{23}$ The papal bull, however, did not definitively solve the question as to if and to what degree beatitude in heaven will increase in intensity following the Last Judgment. ${ }^{24}$ The document's important achievement was to specify the meaning of the term visio beatifica. According to Benedictus Deus, beholding the essence of God is the essence of heaven and of the true beatitude that the saved enjoy immediately after their death. Contrary to what some theologians have claimed, this means that the newly separated soul can behold the essence of God (divina essentia perfuuntur) and is truly blessed (sunt vere beatae) even before the Last Judgment. ${ }^{25}$ In the document, the use of the term "truly" (vere) blessed instead of the adverb "perfectly" (perfecte), which Parisian theologians used, is important with regard to an earlier debate on the topic because "truly" indicates that the visio beatifica is definitely distinct from the state of perfection and cannot be understood in a definitive sense. From this point forward, the visio beatifica could no longer be considered a synonym for perfect beatitude. This approach to the dogma leaves open the question regarding the possibility that the intensity of the experience of the beatific vision intensifies after the Last Judgment. ${ }^{26}$ The way in which Benedict XII uses another term also confirms this possibility. When referring to the beatitude of the saved within the context of Parousia the pope uses the dynamic verb "to continue" (continuabitur) ${ }^{27}$ rather than the static expression "to last" (perpetuoremanebit). The verb continuabitur implies, then, that a potential

23

C. W. Bynum, The Resurrection of the Body in Western Christianity 200-1336, p. 285; W. Szmulewicz, Po tamtej stronie życia, Tarnow 2005, p. 103.

2

A. Tabarroni, "Visio beatifica e Regnum Christi nell'escatologia di Giovanni XXII," in: La cattura della fine. Variazioni dell'escatologia in regime di cristianita, ed. G. Ruggeri, Genova 1992, pgs. 132-139.

H. Denzinger, A. Schönmetzer, Enchiridion Symbolorum, no. 1001.

Por. C. Naumowicz, “Konstytucja Benedykta XII Benedictus Deus,” pgs. 118-119

H. Denzinger, A. Schönmetzer, Enchiridion Symbolorum, no. 1001. 
for increase is possible. ${ }^{28}$ To see God is the essence of heaven in the sense that it is the most important reward for all who are saved and a reward that they will all experience. The condition for enjoying the beatific vision is man's personal holiness, which the document defines as being "not in need of any purification." 29 The papal bull, therefore, defined eternal happiness as a direct vision of God that is accomplished without the mediation of any creature and constitutes the source of eternal joy and rest. When describing eternal happiness, along with the word "vision" (visio) the document includes the phrase "to enjoy" (fruitio) the essence of God,,$^{30}$ which indicates a corporal experience. Hence, eternal happiness should not be understood only in terms of the intellect and cognition, but also in terms of affect..$^{31}$ Moreover, Benedictus Deus mentions the company of angels who partake in the beatitude of the saved. ${ }^{32}$

The Council of Florence of 1439 confirmed Benedictus Deus' teaching on the beatific vision and specified that the souls of the saved, who are in the state of sanctifying grace and have repented of their sins, are immediately admitted to heaven where they see God as He is: one in Catechetics three..$^{33}$ The beatific vision is, therefore, to behold the essence of the Holy Trinity. In this way, the Council of Florence elaborated on the doctrine contained in Benedictus Deus by clarifying that the object of visio beatifica is the essence of the God, or the Holy Trinity Itself. ${ }^{34}$ The Council also added that those who are saved see the Trinity according to their merits, ${ }^{35}$ indicating that the reward that the souls of the saved experience in heaven is proportionate to their merit (pro meritorum diversitate). ${ }^{36}$ This proportionality also applies to the punishment that the souls in hell experience. In other words, the infernal punishment that the damned suffer varies and corresponds proportionately to their sins. The eschatological teachings of the Council of Florence

28 C. Naumowicz believes that there is a continuity of reflection between Popes John XXII and Benedict XII's statements, see: C. Naumowicz, "Konstytucja Benedykta XII Benedictus Deus," pgs. 109-123.

W. Szmulewicz, Po tamtej stronie życia, p. 102.

H. Denzinger, A. Schönmetzer, Enchiridion Symbolorum, nos. 1000-1001.

Por. J. Finkenzeller, Eschatologia, p. 236.

Por. L. F. Ladaria, “Kres człowieka,” p. 400.

H. Denzinger, A. Schönmetzer, Enchiridion Symbolorum, no. 1305.

Por. L. F. Ladaria, “Kres człowieka,” p. 401.

H. Denzinger, A. Schönmetzer, Enchiridion Symbolorum, nos. 1305-1306.

Ibid, no. 1305; See. J. Finkenzeller, Eschatologia, pgs. 108, 237. 
fundamentally elaborated on the teachings of the Second Council of Lyons and Benedictus Deus.

\section{The Existence and Essence of Purgatory}

During the late Middle Ages, another teaching that the Roman Catholic Church discussed was the existence of purgatory and the nature of the purification to which the souls in purgatory are subjected. Purgatory appeared as a contentious issue between the Latin and Greek Churches with marked intensity in the first half of the thirteenth century. The first debates on this subject took place in southern Italy. At that time, the Franciscans represented the Latin Church, while the Bishop of Corfu represented the Eastern Church. ${ }^{37}$ Among other things, the dispute concerned the idea of a purgative fire, which was absent in the Eastern tradition. The Eastern Orthodox Church associated fire with hell and was, therefore, concerned that the Roman Catholic Church believed that purgatory was a part of hell from which souls can be redeemed through purgative fire.

In the conciliar document, purgatory is understood as a purgative Catechetics cleansing after death meant for those who died in a state of God's grace but who did not manage to repent of their venial sins or make reparation for them during their earthly life. The expression used in the so-called Clementine formula "punishments of purgatory through purification" (poenis purgatoriis seu catharterii) contains two important points regarding the doctrine of purgatory. ${ }^{38}$ Firstly, it does not speak of purgatory as a place and, secondly, it does not mention fire (ignis purgatoris). It refers only to the general "punishment of purgatory" (poenis purgatoriis). ${ }^{39}$ The attempt to explain purgatory without referring to it as a place was the result of a certain compromise with the Eastern Orthodox Church, which argued that one cannot speak of purgatory as a place because the soul is separated from the body after

37 R. Ombres, "Latins and Greeks in Debate over Purgatory, 1250-1459," Journal of Ecclesiastical History, 55 (1984), pgs. 1-14.

38 A. Nichols, Rome and the Eastern Churches. A Study in Schism, San Francisco 2010, p. 293.

39 L. F. Ladaria, "Kres człowieka," p. 398; see: J. Le Goff, Narodziny czyśćca, Warsaw 1997, p. 288. Saint Catherine of Genoa wrote about the joy of the souls and their ever-fuller vision of God in purgatory in her Treatise on Purgatory. In Polish see: Sw. Katarzyna z Genoa, Traktat o czyśćcu, II, Warsaw 2003, pgs. 9-14. See also D. Żukowska, "Szczęście w czyśćcu," Resovia Sacra, 13 (2006), p. 107-123. 
death. This dispute arose from the different ways in which the Eastern and the Western Churches understood time, space, and eternity. ${ }^{40}$

At the Council of Florence (1439), the bishops also discussed purgatory in order to continue the Latin Church's attempts to unite with the Eastern Church. Latin interpretations often treated purgatory as a type of temporary hell-a concept that the Eastern Church rejected. A common understanding was achieved, however, in the papal bull Laetentur Coeli, which was issued on July 6, 1439. In this document, the Council of Florence presented an interpretation of the doctrine of purgatory ${ }^{41}$ that repeated the truths contained in the Confession of Faith by Michael Palaiologos, which embraced the concept of purgatory put forth by the Second Council of Lyons. The papal bull also repeated the need to intercede for souls in purgatory and listed the prescribed forms of intercession: Mass, prayer, and almsgiving. ${ }^{42}$ The difference between the Council of Lyons and the Council of Florence's concepts of purgatory was that the latter decided to no longer use the Greek term catharteriae when speaking about the purifying punishment of the souls in purgatory. The Council of Florence nonetheless maintained the general expression "punishment of purgatory" without mentioning "purgative fire" (ignis purgatoris). ${ }^{43}$ In essence, the conciliar doctrine of purgatory speaks of it not as a place but as a process of "purification" (purgari), during which souls experience "purifying punishments" (poenae purgatoriae). It focused on the most important issue of the time, which was to assert the truth of the existence of purgatory as a purification after death that is necessary to prepare the soul to fully participate in the reward of heaven and to stress the importance of prayer for the dead. Purgatory was thus discussed in relation to salvation and using therapeutic terms - an approach that was closer to the Eastern tradition. ${ }^{44}$ According to the conciliar pronouncements, the Church's teaching on purgatory consists of four important elements: being in a state of grace at the moment of death as a condition for being admitted to purgatory; the remnants of sins of commission and omission (de commissis et omissis), which must be purified; purifying punishment; and the purification process itself, which emphasizes,

40 Por. T. Horváth, Eternity and Eternal Life: Speculative Theology and Science in Discourse, pg. 18.

41 H. Denzinger, A. Schönmetzer, Enchiridion Symbolorum, no. 1304.

42 L. F. Ladaria, "Kres człowieka," p. 401.

43 See: Le Goff, Narodziny czyśćca, p. 288; J. Finkenzeller, Eschatologia, p. 132.

44 W.Łydka, "Eschatologia w wypowiedziach Urzędu Nauczycielskiego Kościoła," Ateneum Kapłańskie, 74 (1982), vol. 98, book 1, p. 62. 
once again, the idea of vestiges of sin and just punishment. ${ }^{45}$ The Council of Florence's understanding of purgatory came serve as the basis of the definition of purgatory, which was officially promulgated as a doctrine and an article of faith. ${ }^{46}$

\section{Conclusion}

When summing up the Roman Catholic Church's teaching on eschatological subjects during the late Middle Ages, it is clear that the medieval period played an extremely important role in shaping Catholic teaching on death, judgment, and the destiny of the soul. The particular and Last Judgment, the beatitude that the save experience in heaven, and the existence and essence of purgatory were among the issues raised during this period. The papal bull Benedictus Deus, which defined the most important aspects of particular judgment, was the turning point in the Church's teaching on individual eschatology. It should be noted that the question of the visio beatifica also holds a special place in Catholic teaching. This is because explanations of what, precisely, the beatific vision is provide answers to the question that was at the center of eschatological debate: "When and how will people see God?" Moreover, when answering this question, the Church fathers spoke more about heaven than about hell, which was mentioned in the context of the immediate reward or retribution after death without specifying the type of punishments and their character. Furthermore, although doctrinal statements regarding the existence of purgatory were formulated during this period, these definitions were spiritual (purgatory as a purification process) rather than materialspatial (purgatory as a place).

The historical context in which the Church's teachings on specific aspects of eschatology arose informed the development of these teachings. In other words, the Church's teachings on eschatology arose largely in response to particular issues that were the subject of theological debate and discussion, particularly between the Eastern and Western Churches. As a result, these teachings did not cover all issues related to the fate of man after death and the Last Judgment. Rather, late medieval Catholic teaching on eschatology focused primarily on particular eschatology, while general eschatology, Parousia, and the

\footnotetext{
$45 \quad$ T. D. Łukaszuk, Ostateczny los człowieka, p. 126.

46 B. Hamilton, Religion in the Medieval West, London 1986, pgs. 46-47.
} 
Last Judgment were addressed secondarily. ${ }^{47}$ During the late Middle Ages, the issues that the Roman Catholic Church officially taught could be found in the theology, preaching, and visual representations, which were the main ways by which the Church transmitted the precepts of the faith to Christians at that time.

\section{Bibliography:}

1. Bynum, C. W., The Resurrection of the Body in Western Christianity 2001336, New York 1995.

2. D'Onofrio, G., Historia teologii. Epoka średniowieczna, Cracow 2005.

3. Denzinger, H., Enchiridion symbolorum definitionum et declarationum de rebus fidei et morum, Bologna 2004.

4. Denzinger, H., Schönmetzer A., Enchiridion Symbolorum Definitionum et Declarationum de Rebus Fidei et Morum, Freiburg 1965.

5. Douie, D., "John XXII and Beatific Vision," Dominican Studies 3 (1950) no. 2, pgs. 154-174.

6. Dykmans, M., Les sermons de Jean XXII sur la vision béatifique, Rome 1973.

7. Finkenzeller, J., Eschatologia, Cracow 2000.

8. Hamilton B., Religion in the Medieval West, London 1986.

9. Horváth, T., Eternity and Eternal Life: Speculative Theology and Science in Discourse, Waterloo 1993.

10. Kelly, J. F., The Ecumenical Councils of the Catholic Church: A History, Collegeville 2009.

11. Ladaria, L. F., "Kres człowieka i kres czasów," in: Człowiek i jego zbawienie. Historia dogmatów, ed. B. Susboüé, Cracow 2001, pgs. 355-410.

12. Le Goff, J., Narodziny czyśćca, Warsaw 1997.

13. Łukaszuk, T.D., Ostateczny los człowieka $i$ świata w świetle wiary katolickiej, Cracow 2006.

14. Łydka, W., "Eschatologia w wypowiedziach Urzędu Nauczycielskiego Kościoła," Ateneum Kaptańskie, 74 (1982), vol. 98, z. 1, p. 53-66.

15. Müller-Goldkuhle, P., "Pobiblijne przesunięcie akcentu w historycznym procesie rozwojowym myślenia eschatologicznego," Concilium 30 (1969), nos. 1-4, pgs. 21-31.

16. Naumowicz, C., "Konstytucja Benedykta XII Benedictus Deus. Próba nowego spojrzenia na kontrowersję," Teologia w Polsce, 4 (2010), no. 1, pgs. 109-123.

17. Nichols, A., Rome and the Eastern Churches: A Study in Schism, San Francisco 2010.

18. Nocke, F. J. Eschatologie, Düsseldorf 1982.

19. Ombres, R., "Latins and Greeks in Debate over Purgatory, 1250-1459," Journal of Ecclesiastical History, 55 (1984), pgs. 1-14.

20. Pietras, H., Eschatologia Kościoła pierwszych czterech wieków, Cracow 2007.

$47 \quad$ P. Müller-Goldkuhle, "Pobiblijne przesunięcie akcentu w historycznym procesie rozwojowym myślenia eschatologicznego," Concilium 30 (1969), nos. 1-4, p. 28. 
21. Skowroński, Z., Dyskusje o czyśćcu na Soborze Florenckim, Lodz 1937.

22. St. Catherine of Genoa, Traktat o czyśćcu, Vol. II, Warsaw 2003.

23. Szmulewicz, W., Po tamtej stronie życia, Tarnow 2005.

24. Tabarroni, A., "Visio beatifica e Regnum Christi nell'escatologia di Giovanni XXII," in: La cattura della fine. Variazioni dell'escatologia in regime di cristianita, ed. G. Ruggeri, Genova 1992, pgs. 123-149.

25. Trottmann. C., La vision beatifique. Des disputes scolastiques à sa definition par Benoit XII, Rome 1995.

26. Weakland, J. E., "Pope John XXII and the Beatific Vision Controversy," Annuale mediaevale 9 (1968), pgs. 76-84.

27. Wysocki, M., "Zmartwychwstanie ciała według Tertuliana," Verbum Vitae, 15 (2009), pgs. 295-324.

28. Żukowska, D., "Szczęście w czyśćcu," Resovia Sacra, 13 (2006), pgs. 107-123. 